\title{
Neuroprotective Effects of Agmatine in Experimental Peripheral Nerve Injury in Rats: A Prospective Randomized and Placebo-Controlled Trial
}

\section{Stçanlarda Deneysel Periferik Sinir Yaralanmasında Agmatinin Nöroprotektif Etkileri: Prospektif, Randomize, Plasebo Kontrollü Çalışma}

\author{
Aykut SEZER ${ }^{1}$, Bulent GUCLU ${ }^{1}$, Burak KAZANCI ${ }^{2}$, Murteza CAKIR ${ }^{3}$, Mustafa Kemal COBAN ${ }^{4}$ \\ ${ }^{1}$ Ministry of Health, Serket Yilmaz Research and Training Hospital, Department of Neurosurgery, Bursa, Turkey \\ ${ }^{2}$ Ufuk University, Faculty of Medicine, Department of Neurosurgery, Ankara, Turkey \\ ${ }^{3}$ Ataturk University Hospital, Department of Neurosurgery, Erzurum, Turkey \\ ${ }^{4}$ Ministry of Health, Erzurum Research and Training Hospital, Department of Neurosurgery, Erzurum, Turkey
}

Corresponding Author: Bulent GUCLU / E-mail: guclubulent@hotmail.com

\begin{abstract}
AIM: The purpose of this study was to demonstrate the activity of agmatine, an inducible nitric oxide synthase (iNOS) inhibitor and selective $\mathrm{N}$-methyl-D-aspartate receptor (NMDAR) antagonist, on reducing tissue damage in distal part of traumatic nerve in an experimental rat peripheral nerve injury model.

MATERIAL and METHODS: Sciatic nerves of 30 Sprague Dawley male rats were used. Rats were divided into 5 groups; group 1 ( $n=6)$, control group; group $2(n=6)$, axonotmesis + placebo group; group $3(n=6)$, axonotmesis $+50 \mathrm{mg} / \mathrm{kg}$ agmatine treatment group; group $4(\mathrm{n}=6)$, neurotmesis + placebo group; group $5(\mathrm{n}=6)$, neurotmesis $+50 \mathrm{mg} / \mathrm{kg}$ agmatine treatment group. Axonolysis, axon degeneration, edema, hemorrhage, and inflammation were evaluated in histopathologic examinations of all the groups.

RESULTS: When group 2 was compared with group 3 in histopathologic sections, axonolysis was less in group 3 ( $p=0.007$ ), as was axon degeneration $(p=0.022)$ and edema $(p=0.018)$. When group 4 was compared with group 5 , axonolysis was less in group $5(p=0.009)$, as was axon degeneration $(\mathrm{p}=0.006)$ and edema $(\mathrm{p}=0.021)$.

CONCLUSION: This study demonstrated agmatine to have antioxidant and antineurotoxic effects in an experimental rat peripheral nerve injury model.
\end{abstract}

KEYWORDS: Agmatine, Axonotmesis, Neurotmesis, Peripheral nerve injury, Rat

Öz

AMAÇ: Bu çalışmanın amacı, indüklenebilir nitrik oksit sentetaz inhibitörü (iNOS) ve selektif N-metil-D-aspartat reseptörü (NMDAR) antagonisti olan agmatinin sıçanlarda yapılan deneysel periferik sinir yaralanma modelinde hasarlı sinirin distal bölumündeki doku hasarını azaltmadaki etkisini göstermekti.

YÖNTEM ve GEREÇLER: Otuz tane Sprague Dawley sıçanının siyatik sinirleri kullanıldı. Sıçanlar beş gruba bölündü: birinci grup ( $n=6)$, kontrol grubu; ikinci grup $(n=6)$, aksonotmezis + plasebo grubu; üçüncü grup $(n=6)$, aksonotmezis $+50 \mathrm{mg} / \mathrm{kg}$ agmatin tedavi grubu; dördüncü Grup $(n=6)$, neurotmesis + plasebo grubu; beşinci grup $(n=6)$, neurotmesis $+50 \mathrm{mg} / \mathrm{kg}$ agmatin tedavi grubu. Aksonolizis, akson dejenerasyonu, ödem, hemoraji ve inflammasyon bütün gruplarda histopatolojik olarak değerlendirildi.

BULGULAR: İkinci grup ile üçüncü grup histopatolojik kesitlerde kıyasladığında, aksonolizis üçüncü grupta daha azdı ( $p=0,007)$, aynı şekilde akson dejenerasyonu $(p=0,022)$ ve ödem $(p=0,018)$ üçüncü grupta daha azdı. Dördüncü grup ile beşinci grup histopatolojik kesitlerde kıyasladığında, aksonolizis beşinci grupta daha azdı $(p=0,009)$, aynı şekilde akson dejenerasyonu $(p=0,006)$ ve ödem $(p=0,021)$ beşinci grupta daha azdı.

SONUÇ: Bu çalışma, agmatinin sıçanlarda yapılan deneysel periferik sinir yaralanmalarında antioksidan ve antinörotoksik etkileri olduğunu göstermiştir.

ANAHTAR SÖZCÜKLER: Agmatin, Aksonotmezis, Nörotmezis, Periferik sinir yaralanması, Sıçan 


\section{INTRODUCTION}

Peripheral nerve injury is a common health problem that often results in both social and economic losses for the victim (2). Peripheral nerve injury may occur as a result of trauma (blunt or penetrating) or acute compression and result in demyelination or axonal degeneration. Clinically, both demyelination and axonal degeneration result in disruption of the sensory and/or motor function of the injured nerve. Recovery of function occurs with the remyelination, axonal regeneration and reinnervation of the sensory receptors, muscle end plates, or both. No definitive treatment for peripheral nerve injuries exists. Functional recovery after peripheral nerve injury is often poor; however, unlike in the central nervous system, regeneration in the peripheral nervous system is possible (4). New therapies that protect injured peripheral neurons and enhance regeneration are needed. The purpose of this study was to demonstrate the activity of agmatine, an inducible nitric oxide synthase (iNOS) inhibitor and selective N-methyl-D-aspartate receptor (NMDAR) antagonist, on reducing tissue damage in distal part of trauma in an experimental rat peripheral nerve injury model.

\section{MATERIAL and METHODS}

\section{I- Laboratory Study}

This experimental study was conducted in the Animal Laboratory of the Pharmacology Department, Histology Department, Pathology Department, and Neurosurgery Department of Ataturk University / Erzurum / Turkey. The approval of the Ethics committee approval was obtained for the study from the Local Research Ethics Commitee.

This study involved thirty male Sprague Dawley rats. Rats were divided into 5 groups (with 6 rats in each group). The rats were numbered with ear tags. The rats in all of the groups were sedated with intraperitoneal thiopental (Pental Sodyum, Ulagay, Istanbul, Turkey). The right gluteal area of the rats was shaved and disinfected with $10 \%$ polyvinylpyrrolidone/ iodine. The surgery was conducted on the rats in the prone position. A $2 \mathrm{~cm}$ longitudinal skin incision was made in the right gluteal area along the length of the sciatic nerve, and the sciatic nerve was exposed. The sciatic nerves in group 1 $(n=6)$ were exposed, and only physiological sodium chloride solution $(0.7 \% \mathrm{NaCl})$ was applied intraperitoneally every day for a duration of 10 days as a control group. The siatic nerves in group $2(n=6)$ were clamped with a $12.5 \mathrm{~cm}$-long clamp for one minute and then released in order to produce axonotmesis, and physiological sodium chloride solution $(0.7 \% \mathrm{NaCl})$ solution was applied intraperitoneally every day for a duration of 10 days in order to produce the axonotmesis + placebo group. The sciatic nerves in group $3(n=6)$ were clamped with a $12.5 \mathrm{~cm}$-long clamp for one minute and then released in order to produce axonotmesis, and $50 \mathrm{mg} / \mathrm{kg}$ agmatine was applied intraperitoneally for 10 days in order to produce the axonotmesis + agmatine treatment group.
The sciatic nerves in group $4(n=6)$ were cut with a number 10 blade, and neurorraphy was then performed by microsurgical technique using $8 / 0$ nylon suture to produce neurotmesis, and physiological saline solution was applied intraperitoneally for 10 days for the neurotmesis + placebo group. Sciatic nerves in group $5(n=6)$ were cut with a number 10 blade, and then neurorraphy was performed by microsurgical technique using $8 / 0$ nylon suture in order to produce neurotmesis, and $50 \mathrm{mg} /$ $\mathrm{kg}$ agmatine was applied intraperitoneally for 10 days in order to produce the neurotmesis + agmatine treatment group. In all of the groups, the anatomical layers were sutured after performing experimental peripheral nerve injury, and the wound was treated with betadine for 10 days. After feeding the rats for 5 more days (total 15 days after surgery), they were sedated with intraperitoneal thiopental (Pental Sodyum, Ulagay, İstanbul), and approximately $1.5-2 \mathrm{~cm}$ of sciatic nerves were removed for microscopic analysis and comparison. The sciatic nerves were then fixed in $4 \%$ formaldehyde for 5 days.

Sciatic nerve samples were taken proximal to the lesion, the lesion site, and distal to the lesion for all the groups, and these parts were embedded in paraffin blocks. Three sections were taken from every block in order to make a better evaluation, and the sections were stained with Hematoxylin and Eosin. Injury scores were obtained by evaluating the sections with a light microscope. The sciatic nerve sections in the axonotmesis + placebo group (group 2) showed mild injury in the proximal site, and severe injury in the lesion and distal sites. The sciatic nerve sections in axonotmesis $+50 \mathrm{mg} / \mathrm{kg}$ agmatine group (group 3) showed mild injury in the proximal site and moderate injury in the lesion and distal sites. The sciatic nerve sections in the neurotmesis + placebo group (group 4) showed mild-moderate injury in the proximal and lesion sites, and severe injury in the distal site. The sciatic nerve sections in the neurotmesis $+50 \mathrm{mg} / \mathrm{kg}$ agmatine group (group 5) showed mild injury in the proximal site and moderate injury in the lesion and distal sites. Damage was more prominent in the distal part of the nerves, and only the distal parts of the nerves were evaluated and compared in this study.

\section{II- Statistical Examination}

Axonolysis, axon degeneration, edema, hemorrhage, and inflammation were evaluated in the histopathologic examination of the distal sites of the sciatic nerves in groups $2,3,4$, and 5 and were compared with the control group. Axonolysis, axon degeneration, edema, hemorrhage, and inflammation were graded as $0,1,2$, or 3 according to a modified grading system described by Wahl et al. (22) (Table I). A light microscope with both $20 x$ and $40 x$ magnification was used in evaluating the histopathologic specimens, and final grades of axonolysis, axon degeneration, edema, hemorrhage, and inflammation were obtained for all of the nerves. Statistical comparisons were conducted using the Independent Samples t Test, and the results were evaluated using the Mann-Whitney $U$ test; $p<0.05$ was accepted as statistically significant. 
Table I: Table Showing Criteria of Histopathologic Scoring Depending on Axonolysis, Axon Degeneration, Edema, Hemorrhage, and Inflammation

\begin{tabular}{|l|c|c|}
\hline Grade of damage & Percentage of damage & Score \\
\hline No damage & $0 \%$ & 0 \\
\hline Minor damage & $25 \%>$ & 1 \\
\hline Moderate damage & $25 \%-75 \%$ & 2 \\
\hline Severe damage & $75 \%<$ & 3 \\
\hline
\end{tabular}

\section{RESULTS}

\section{I- Light Microscopic Evaluation}

The sections taken from the control group (group 1) were evaluated under a light microscope and normal axon, vascular, and connective tissue structures were seen (Figure 1). Nerve sections of the distal parts of trauma in the axonotmesis + placebo group (group 2) revealed severe axonolysis, degenerated ghost axons, migrated inflammatory cells, and severe edema in the connective tissue when evaluated under a light microscope (Figure 2). Nerve sections of the distal parts of trauma in the axonotmesis + agmatine treatment group (group 3) displayed some intact axons, a moderate degree of axonolysis, degenerated ghost axons, and moderate edema when evaluated under a light microscope (Figure 3). Nerve sections of the distal parts of trauma in the neurotmesis + placebo group (group 4) showed severe axonolysis, degenerated ghost axons, degenerated myelin sheaths, and intense edema when evaluated under the light microscope (Figure 4). Nerve sections of the distal parts of trauma in the neurotmesis + agmatine group (group

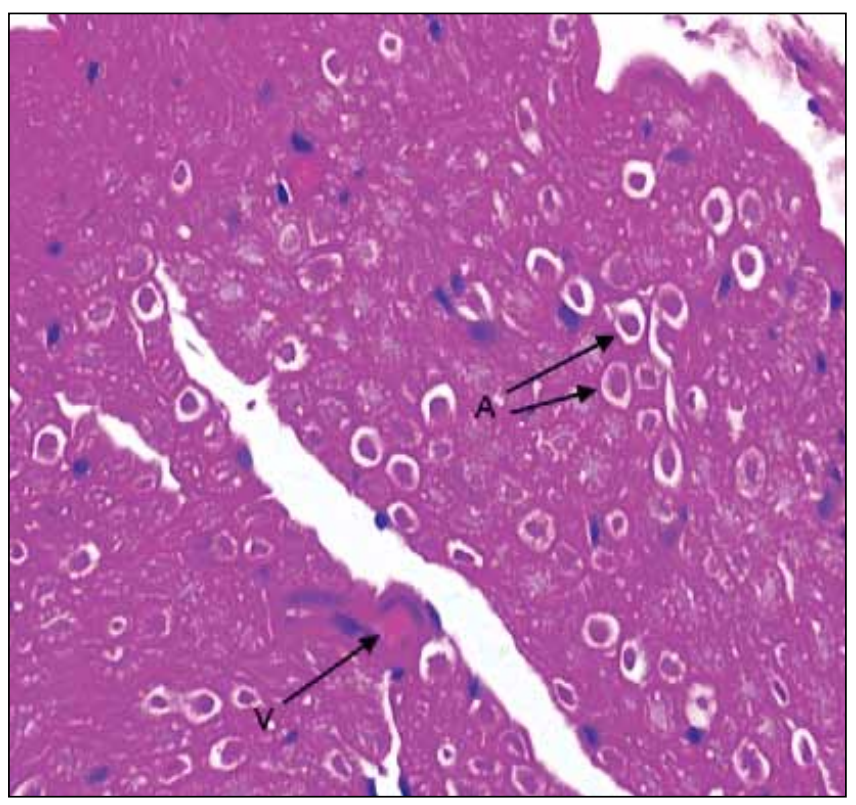

Figure 1: Light microscopic examination (HE staining) of sciatic nerve of control group showing normal axonal structure (A), normal peripheral nerve vascular structure (V), and normal structure of connective tissue (x40).

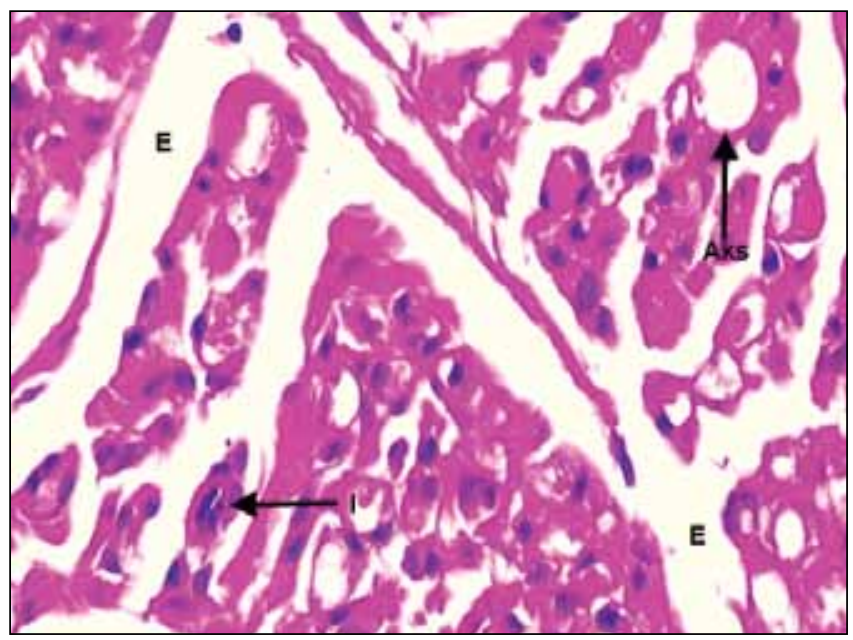

Figure 2: Light microscopic examination (HE staining) of the distal part of the sciatic nerve of the axonotmesis + placebo group showing axonolysis (Aks), a large number of ghost axons that are degenerated, inflammatory cells migrating (I) out of vessels, and edema (E) (x40).

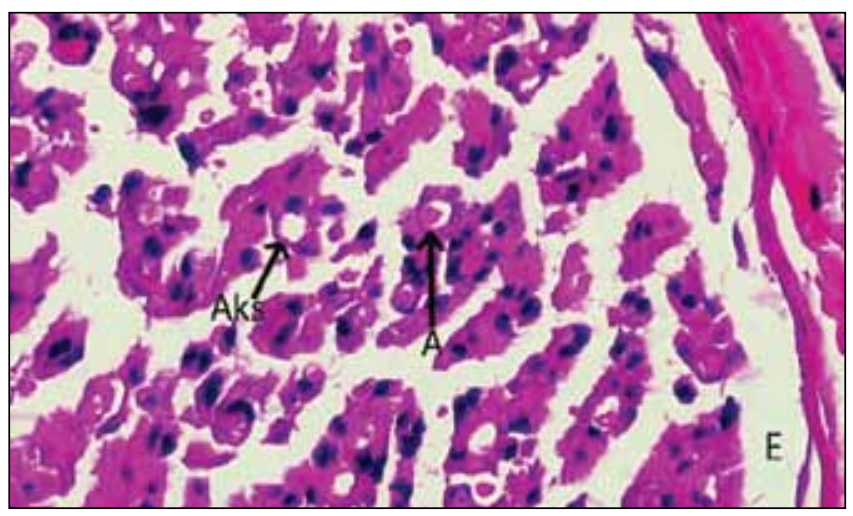

Figure 3: Light microscopic examination (HE staining) of the distal part of the sciatic nerve of the axonotmesis $+50 \mathrm{mg} / \mathrm{kg}$ agmatine treatment group showing less axonolysis (Aks) and degenerated axons and less edema (E). Some normal axonal structure $(\mathbf{A})$ is also seen $(x 20)$.

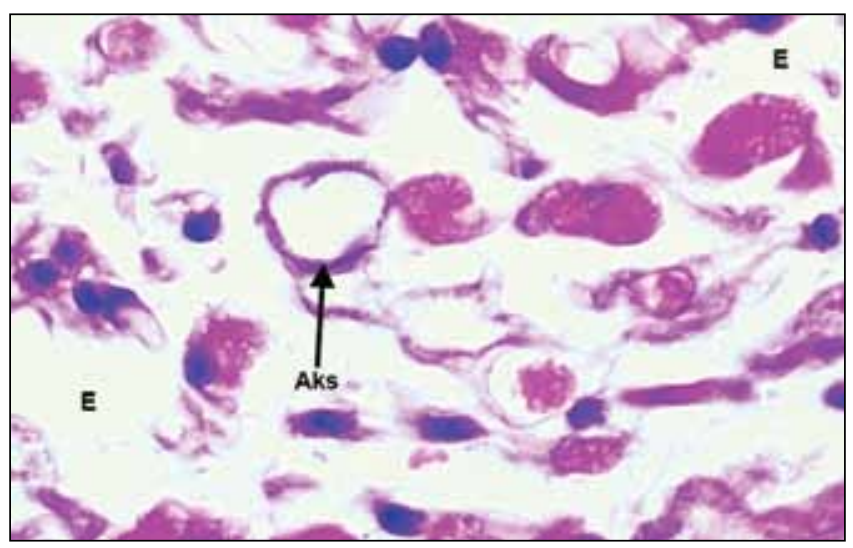

Figure 4: Light microscopic examination (HE staining) of the distal part of the sciatic nerve of the neurotmesis + placebo group showing intense edema (E), axonolysis (Aks), and large number of ghost axons that are degenerated (x40). 


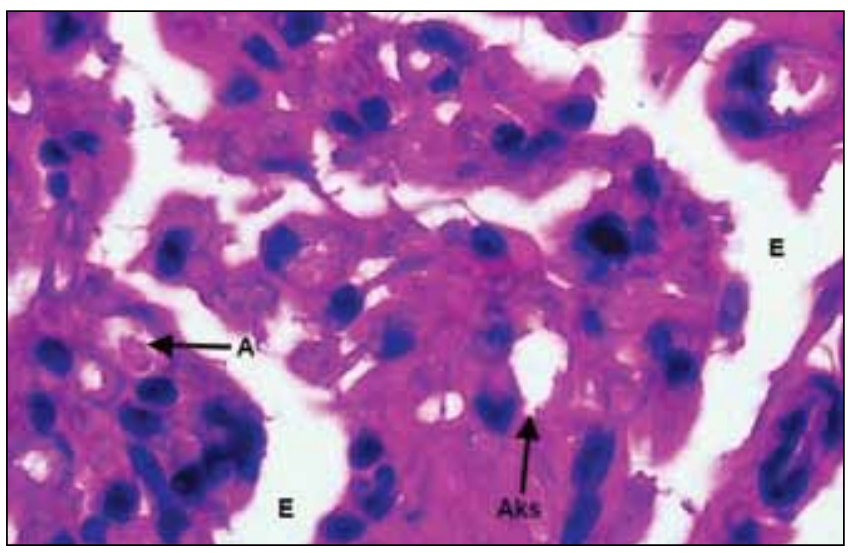

Figure 5: Light microscopic examination (HE staining) of the distal part of the sciatic nerve of the neurotmesis $+50 \mathrm{mg} / \mathrm{kg}$ agmatine treatment group showing some intact axons beside axonolysis (Aks) and ghost axons that are degenerated. There is less edema (E) compared with the neurotmesis + placebo group (x40).

5) revealed some intact axons, moderate edema, axonolysis, degenerated ghost axons, and degenerated myelin sheaths when evaluated under the light microscope (Figure 5).

\section{II-Statistical Examination}

When the axonotmesis + placebo group (group 2) was compared with the axonotmesis $+50 \mathrm{mg} / \mathrm{kg}$ agmatine treatment group (group 3) in the histopathologic sections, axonolysis was less in group $3(p=0.007)$, as was axon degeneration $(p=0.022)$ and edema $(p=0.018)$. As these values are less than 0.05 , they were accepted to be statistically significant. For hemorrhage and inflammation, p was 0.89 and 0.118 , respectively; these values were statistically insignificant. When the neurotmesis + placebo group (group 4) was compared with the neurotmesis $+50 \mathrm{mg} / \mathrm{kg}$ agmatine treatment group (group 5) in the histopathologic sections, axonolysis was less in group $5(p=0.009)$, as was axon degeneration $(p=0.006)$ and edema $(p=0.021)$. As these values are less than 0.05 , they were accepted to be statistically significant. For hemorrhage and inflammation, $p$ was 0.75 and 0.269 , respectively; these values were statistically insignificant.

\section{DISCUSSION}

Peripheral nerve injury causes a high rate of disability and a tremendous economic burden and is currently a major health problem (2). Traffic accidents, industrial accidents, and gunshot and knife wounds are major causes of these injuries. Peripheral nerve injury may result in demyelination or axonal degeneration. Clinically both demyelination and axonal degeneration result in disruption of the sensory and/or motor function of the injured nerve. Recovery of function occurs with remyelination, axonal regeneration and reinnervation of the sensory receptors, muscle end plates, or both. No definitive treatment for peripheral nerve injuries exists.

The proper classification of peripheral nerve injuries assists in the prognosis and determination of appropriate treatment strategies. A system of classification of nerve injuries was described by Seddon (18) in 1943 and by Sunderland (19) in 1951. Categorization of peripheral nerve injuries in the Seddon classification is based on the extent of damage to both the nerve and the surrounding connective tissue since the nervous system is characterized by the dependence of neurons on their supporting glia. According to Seddon's classification, the lowest degree of nerve injury, in which the nerve remains intact but signaling ability is damaged, is called neurapraxia. The second degree, in which the axon is damaged but the surrounding connective tissue remains intact, is called axonotmesis. The last degree, in which both the axon and connective tissue are damaged, is called neurotmesis (18).

Treatment of peripheral nerve injuries is considered to be a challenging procedure. Treatment of these injuries varies depending on the type of the injury, place of the injury, condition of the surrounding structures, and associated injuries. Generally, the surrounding structures are minimally injured. Surgical and medical methods are used to treat peripheral nerve injury. The literature presents numerous experimental peripheral nerve injury models, and different materials were used to treat the injuries. We selected our model as to avoid injuring surrounding structures. In the treatment of peripheral nerve injuries, suturing with vinyl and silk was done first; however in light of the number of sutures and the negative effects of the sutures on recovery, fibrin glue and wrapping the injured nerve were also tried. Electrical stimulation, therapeutic ultrasound, low-dose radiation, and low-intensity laser were also tested in experimental models to produce nerve regeneration and functional recovery $(8,13$, $15,16,17)$.

After peripheral nerve injury, some surgeons advise immediate repair, while others advise recommend waiting some weeks (Seddon). In the lesion site of a peripheral nerve injury, the decrease in oxygenation and changes in morphology increase arachidonic acid metabolism. Unstable endoperoxides collect in intracellular and extracellular areas. These substances are superoxidized and are converted to superoxide anion radicals. To begin recovery, these free oxygen radicals should be removed and should no longer be produced. The processes that occur in peripheral regeneration can be divided into the following major events: Wallerian degeneration, axon regeneration/growth, and nerve reinnervation. Wallerian degeneration, the self-destructive set of cellular and molecular processes by which degenerating axons and myelin are cleared after injury, is initiated by macrophages and Schwann cells. Molecular inflammatory mediators such as cytokines (IL-1, IL-6, IL-10, and TNF-alpha, among others), transcription factors (NF-kappaB, c-Jun), the complement system and arachidonic acid metabolites have been shown in various studies to modulate these processes (1). Furthermore, the alteration of spinal arachidonic acid turnover after peripheral nerve injury regulates regional glutamate uptake activity and glutamate homeostasis (20). 
Agmatine [4-(aminobutyl)-guanidine- $\mathrm{NH} 2-\mathrm{CH} 2-\mathrm{CH} 2-\mathrm{CH} 2-\mathrm{CH}$ 2-NH-C(-NH2)(=NH)] is a guanidinium compound formed by the decarboxylation of I-arginine by arginine decarboxylase, and found in abundace in bacteria, and plants (21) and in trace amounts in mammalians (9). Agmatine is a neurotransmitterneuromodulator with both $\mathrm{N}$-methyl-d-aspartate receptor (NMDAR)-antagonizing and nitric oxide synthase (NOS)inhibiting activities. The compound is present in the brain in very low amount; however, its synthesis is greatly increased during brain development and after brain ischemia (6). Agmatine plays a role in the modulation of neurotransmission functions and interacts with various neurotransmitter receptors (7). Agmatine can also interfere with second messenger pathways by acting as an adenosine diphosphate (ADP)-ribose acceptor and inhibits ADP-ribosylation of proteins (14). As a result of these characteristics, agmatine has certain neuroprotective effects after neurotrauma. Treatment with exogenous agmatine has been found to be non-toxic and to exert significant neuroprotective effects in models of neurotoxic and ischemic brain injuries $(5,11,12)$. Treatment with agmatine has also been found to be neuroprotective following excitotoxic spinal cord injury $(3,10,23)$.

In summary, the present findings demonstrate that agmatine treatment can exert significant neuroprotective effects in the experimental model of peripheral nerve injury and suggests that this naturally occurring, non-toxic compound should be tried for therapeutic use after peripheral nerve injury. Limitations of this study are the small number of rats, lack of knowledge on the minimum effective dose, minimum duration of usage, and the best way of administration of agmatine. This is the first study demonstrating the activity of agmatine, an inducible NOS (iNOS) inhibitor and selective NMDAR antagonist, on reducing tissue damage in distal part of trauma in an experimental peripheral nerve injury in rats. However, further studies should be conducted prior to the use of agmatine as a drug.

The purpose of this study was to demonstrate the activity of agmatine, an inducible NOS (iNOS) inhibitor and selective NMDAR antagonist, on reducing tissue damage in distal part of trauma in an experimental peripheral nerve injury in rats. In the literature, agmatine was used early in the process of the nerve injury in all studies about the effects of agmatine in neural tissue. Therefore in our study we also used agmatine early in the process of the nerve injury. The results of our study indicate that intraperitoneally administrated agmatine (50 $\mathrm{mg} / \mathrm{kg}$ ) had antioxidant and antineurotoxic effects and positive effects on recovery in experimental peripheral nerve injury in rats. Agmatine reduced axonalysis, axon degeneration, and edema. This effect is thought to be caused by NMDA blockage of agmatine, blockage of the production of NO, which, in turn, blocks peroxidation and decreases apoptosis, enabling cell function to continue. Nevertheless, additional studies examining the effective dose, side effects, and duration of usage of agmatine are recommended.

\section{REFERENCES}

1. Cámara-Lemarroy CR, Guzmán-de la Garza FJ, FernándezGarza NE: Molecular inflammatory mediators in peripheral nerve degeneration and regeneration. Neuroimmunomodulation 17:314-324, 2010

2. Dagum AB: Peripheral nerve regeneration, repair, and grafting. J Hand Ther 11:111-117, 1998

3. Fairbanks CA, Schreiber $\mathrm{KL}$, Brewer $\mathrm{KL}, \mathrm{Yu} \mathrm{CG}$, Stone LS, Kitto KF, Nguyen HO, Grocholski BM, Shoeman DW, Kehl LJ, Regunathan S, Reis DJ, Yezierski RP, Wilcox GL: Agmatine reverses pain induced by inflammation, neuropathy, and spinal cord injury. Proc Natl Acad Sci USA 97:10584-10589, 2000

4. Fenrich K, Gordon T: Canadian Association of Neuroscience review: Axonal regeneration in the peripheral and central nervous systems-current issues and advances. Can J Neurol Sci 31:142-156, 2004

5. Gilad GM, Salame K, Rabey JM, Gilad VH: Agmatine treatment is neuroprotective in rodent brain injury models. Life Sci 58:41-46, 1996

6. Gilad GM, Gilad VH, Rabey JM: Arginine and ornithine decarboxylation in rodent brain: Coincidental changes during development and after ischemia. Neurosci Lett 216:33-36, 1996

7. Gliad GM, Gliad FH: Accelerated functional recovery and neuroprotection by agmatine after spinal cord ischemia in rats. Neurosciences Let 296:97-100, 2000

8. Gocmen S, Sirin S, Oysul K, Ulas UH, Oztas E: The effects of low-dose radiation in the treatment of sciatic nerve injury in rats. Turk Neurosurg 22:167-173, 2012

9. Li G, Regunathan S, Barrow CJ, Eshraghi J, Cooper R, Reis DJ: Agmatine: An endogenous clonidine- displacing substance in the brain. Science 263:966-968, 1994

10. Kotil K, Kuscuoglu U, Kirali M, Uzun H, Akçetin M, Bilge T: Investigation of the dose-dependent neuroprotective effects of agmatine in experimental spinal cord injury: A prospective randomized and placebo-control trial. J Neurosurg Spine 4:392-399, 2006

11. Kuo JR, Lo CJ, Chio CC, Chang CP, Lin MT: Resuscitation from experimental traumatic brain injury by agmatine therapy. Resuscitation 75:506-514, 2007

12. Kuo JR, Lo CJ, Chang CP, Lin KC, Lin MT, Chio CC: Agmatinepromoted angiogenesis, neurogenesis, and inhibition of gliosis-reduced traumatic brain injury in rats. J Trauma 71: 87-93, 2011

13. Mendonca AC, Barbieri $\mathrm{CH}$, Mazzer N: Directly applied low intensity direct electric current enhances peripheral nerve regeneration in rats. J Neurosci Methods 129:183-190, 2003

14. Murayama T, Tsai SC, Adamik R, Moss J, Vaughan M: Effects of temperature on ADP-ribosylation factor stimulation of cholera toxin activity. Biochemistry 32:561-566, 1993

15. Raso VV, Barbieri CH, Mazzer N, Fasan VS: Can therapeutic ultrasound influence the regeneration of peripheral nerves? J Neurosci Methods 142:185-192, 2005 
16. Rochkind S, Leider-Trejo L, Nissan M, Shamir MH, Kharenko O, Alon M: Efficacy of 780-nm laser phototherapy on peripheral nerve regeneration after neurotube reconstruction procedure (double-blind randomized study). Photomed Laser Surg 25:137-143, 2007

17. Rochkind S, Drory V, Alon M, Nissan M, Ouaknine GE: Laser phototherapy $(780 \mathrm{~nm})$, a new modality in treatment of long-term incomplete peripheral nerve injury: A randomized double-blind placebo-controlled study. Photomed Laser Surg 25:436-442, 2007

18. Seddon HJ: Three types of nerve injury. Brain 66:237-288, 1943

19. Sunderland SA: Classification of peripheral nerves injuries producing loss of function. Brain 74:491-516, 1951
20. Sung B, Wang S, Zhou B, Lim G, Yang L, Zeng Q, Lim JA, Wang JD, Kang JX, Mao J: Altered spinal arachidonic acid turnover after peripheral nerve injury regulates regional glutamate concentration and neuropathic pain behaviors in rats. Pain 131:121-131, 2007

21. Tabor CW, Tabor H: Polyamines. Annu Rev Biochem 53:749790, 1984

22. Wahl F, Renou E, Mary V, Stutzmann JM: Riluzole reduces brain lesions and improves neurological function in rats after a traumatic brain injury. Brain Res 756:247-255, 1997

23. Yu CG, Marcillo AE, Fairbank CA, Wilcox GL, Yezierski RP: Agmatine improves locomotor function and reduces tissue damage following spinal cord injury. Neuroreport 11: 3203-3207, 2000 